\title{
MENUJU KEHAMILAN YANG SEHAT DENGAN BEBAS ANEMIA DI ERA PANDEMI COVID-19
}

\author{
Revinel' ${ }^{1}$, Aning Subiyatin ${ }^{2)}$ \\ 1)Program Studi Profesi Bidan, Fakultas Kedokteran dan Kesehatan, Universitas Muhammadiyah Jakarta, \\ Jakarta, Indonesia \\ 2)Sarjana Kebidanan, Fakultas kedokteran dan Kesehatan, Fakultas Kedokteran dan Kesehatan, \\ Universitas Muhammadiyah Jakarta, Jakarta, Indonesia \\ Corresponding author :Revinel \\ E-mail : revinel@umj.ac.id
}

Diterima 15 November 2021, Disetujui 19 November 2021

\begin{abstract}
ABSTRAK
Masa pandemi Covid-19 di Indonesia sangat berdampak di berbagai sektor layanan publik, terutama sektor layanan kesehatan khususnya pemanfaatan layanan Antenatal Care (ANC). Pemerintah merekomendasikan menunda pemeriksaan kehamilan ke tenaga kesehatan kecuali ibu mengalami tanda - tanda bahaya kehamilan. Terkait dengan kondisi ibu hamil tetap harus mendapatkan informasi yang adekuat dan terpantau kesehatannya maka diperlukan kelas ibu hamil guna meningkatkan pengetahuan tentang kehamilan, persalinan, nifas dan parenting. Pengabdian kepada masyarakat bertujuan untuk memberdayakan kelompok ibu hamil dalam meningkatkan pengetahuan dan merubah sikap dan perilaku ibu hamil agar memahami tentang kehamilan yang sehat tanpa anemia agar dapat mencegah komplikasi secara dini selama masa kehamilan dan dapat mempersiapkan persalinan normal, mengikuti protokol kesehatan secara optimal. Metode yang diberikan melalui edukasi interaktif, dengan pendekatan secara langsung, curah pendapat, ceramah, tanya jawab tentang pencegahan anemia pada kehamilan, diikuti 19 ibu hamil dibagi 2 kelompok di Puskesmas kecamatan Tanah Abang. Hasilnya menunjukkan bahwa terjadi peningkatan rata-rata skor pengetahuan sebesar dari $70,53 \pm 26,34$ SD menjadi $88,94 \pm 14,48$ SD.
\end{abstract}

Kata kunci: anemia; ibu hamil; kelas ibu hamil.

\begin{abstract}
The Covid-19 pandemic in Indonesia has greatly impacted various public service sectors, especially the health service sector, especially the use of Antenatal Care (ANC). The government recommends postponing Antenatal Care to health workers unless the mother experiences danger signs of pregnancy. Regarding the condition of pregnant women, they still have to get adequate information and their health is monitored, so a class for pregnant women is needed to increase knowledge about pregnancy, childbirth, postpartum and parenting. Community service aims to empower groups of pregnant women in increasing knowledge and changing attitudes and behavior of pregnant women in order to understand about a healthy pregnancy without of anemia in order to prevent complications early during pregnancy and be able to prepare for normal delivery, following health protocols optimally. The method provided was through interactive education, with a direct approach, brainstorming, lectures, questions and answers about preventing anemia in pregnancy, followed by 19 pregnant women divided into 2 groups at the Tanah Abang sub-district health center. The results showed that there was an increase in the average knowledge score from $70.53 \pm 26.34$ SD to $88.94 \pm 14.48$ SD.
\end{abstract}

Keywords: anemia; pregnant women; class of pregnant women.

\section{PENDAHULUAN}

Anemia merupakan kondisi

berkurangnnya konsentrasi hemoglobin dalam sirkulasi darah, sehingga tidak mampu memenuhi fungsinya membawa oksigen keseluruh jaringan tubuh (Gari et al., 2020). Ibu hamil mengalami anemia apabila kadar hemoglobin di dalam darah kurang dari $11 \mathrm{gr} / \mathrm{dl}$ (Saifudin et al., 2008). Angka Kematian lbu (AKI) merupakan indikator yang dapat mengambarkan status kesehatan ibu di suatu wilayah, di Indonesia saat ini masih memprioritaskan upaya-upaya dalam peningkatan derajat kesehatan lbu dan anak, terutama pada kelompok ibu hamil, bersalin dan bayi pada masa perinatal. Prevalensi anemia ibu hamil sebesar 37,1\% pada tahun 2013, meningkat sebesar 48,9\%. (Kemenkes RI, 2019) 
Penyebab anemia dilaporkan sebagian besar adalah kekurangan zat besi (Fe). Salah satu strategi pencegahan anemia pada kehamilan dengan mengkonsumsi secara rutin tablet zat besi minimal 90 tablet selama kehamilan. Tablet zat besi yang diberikan mengandung FeSO4 320 mg (zat besi $60 \mathrm{mg}$ ) dan asam folat $0,25 \mathrm{mg}$, namun hasilnya belum memuaskan (Kemenkes RI, 2019). Anemia pada ibu hamil akan berdampak pada gangguan pertumbuhan dan perkembangan janin, serta berpotensi terjadinya komplikasi selama kehamilan dan persalinan, bahkan menyebabkan kematian ibu dan anak (Crispin et al., 2019). Situasi pandemi Covid-19, pemerintah mengeluarkan kebijakan salah satunya menunda pemeriksaan kehamilan ke pelayanan kesehatan, kecuali apabila ada tanda-tanda bahaya pada kehamilan (Kemenkes R.I, 2020).

Selama kehamilan seorang ibu akan mengalami perubahan fisik dan psikologis, karena hal tersebut banyak ibu yang merasa terganggu (Kementerian Kesehatan Republik Indonesia, 2015; Rofi'ah et al., 2020). Selama masa kehamilan ibu tetap harus terjaga kesehatannya dan perlu mendapatkan pendidikan kesehatan ibu dan anak. Kelas ibu hamil merupakan kelompok belajar, berbagi informasi kesehatan seputar masa kehamilan, persalinan, perawatan nifas, perawatan bayi baru lahir, dan persiapan menjadi seorang ibu. (Patriajati \& Sriatmi, 2019). kelas ibu hamil agar dapat memberdayakan kelompok ibu hamil dalam meningkatkan pengetahuan dan merubah sikap dan perilaku ibu hamil (Kementrian Kesehatan RI, 2020), agar memahami tentang kehamilan yang sehat, dan dapat mencegah komplikasi secara dini selama masa kehamilan dalam rangka mempersiapkan persalinan normal dengan mengikuti protokol kesehatan secara optimal.

Permasalahan yang didapat di wilayah mitra adalah pemukiman padat penduduk, menurut data BPS Provinsi DKI Jakarta Kepadatan penduduk di Kecamatan Tanah Abang yang memiliki 7 Kelurahan mencapai 13.540 per km2. Dalam masa pandemi Covid19 masih kurangnya kesadaran masyarakat untuk mematuhi protokol kesehatan (WHO, 2020), hal ini menimbulkan kecemasan pada ibu hamil untuk melakukan ANC, sehingga ibu hamil enggan datang memeriksan kehamilannya ke puskesmas dengan alasan khawatir tertular Covid 19. Berdasarkan hasil penelitian sebelumnya yang dilakukan oleh penulis diketahui ibu hamil mengalami anemia ringan selama pandemi Covid 19 sebesar 128 (92.8\%), sedangkan $\mathrm{Hb}$ rata-rata $9.98 \mathrm{gr} / \mathrm{dl}$ dan kadar $\mathrm{Hb}$ yang sering dialami pada level 10.6 $\mathrm{gr} / \mathrm{dl}, \mathrm{Hb}$ terendah 8.1 dan $\mathrm{Hb}$ tertingginya 10.9 $\mathrm{gr} / \mathrm{dl}$, ini menjadi salah satu kelompok yang harus mendapatkan perhatian ekstra di tengah pandemi Covid-19, "Menuju Kehamilan Yang Sehat Dengan Bebas Anemia".

\section{METODE}

Kegiatan pengabdian kepada masyarakat mengacu pada hasil penelitian sebelumnya yang telah dilakukan di lokasi mitra dan atas permintaan dari mitra untuk memberikan Pendidikan kesehatan pada ibu hamil dengan metode memberikan edukasi, diskusi dan tanya jawab. Tentang pencegahan anemia pada kehamilan di masa pandemic Covid -19. Pengabdian kepada masyarakat dilakukan di Puskesmas kecamatan Tanah Abang pada tanggal 31 Mei 2021.

Tahap pelaksanaan dengan melakukan identifikasi/mendaftar semua ibu hamil yang datang ke puskesmas Tanah Abang sebanyak 19 ibu hamil yang terbagi 2 kelompok, yang terdiri dari 10 dan 9 ibu hamil. Kegiatan dilakukan secara bergantian dengan waktu 30 menit per kelompok dengan menerapkan protokol kesehatan sesuai dengan kebijakan pemerintah pada masa pandemic Covid-19.

Melakukan pre test sebelum mendapat materi tentang anemia pada kehamilan. Tujuannya untuk mengetahui sejauh mana tingkat pengetahuan ibu hamil tentang anemia pada kehamilan terdiri dari 10 pertanyaan tentang anemia pada kehamilan.

Pemaparan materi meliputi definisi anemia, penyebab anemia, faktor risiko anemia, tanda gejala anemia, dampak anemia, afaat zat besi, dan sumber-sumber zat besi. Setelah pemaparan dilanjutkan diskusi.

Post test kegiatan ini dilakukan kepada peserta yang mengikuti kegiatan penyuluhan dari awal sampai akhir, bertujuan untuk melihat sejauh mana efektivitas kegiatan edukasi yang dilakukan kepada ibu hamil.

Hasil pre test dan post test ini selanjutnya dilakukan analisis statistik, mengunnakan perangkat SPSS dengan uji t.

\section{HASIL DAN PEMBAHASAN}

Hasil yang didapatkan pada kegiatan pengabdian kepada masyarakat ini adalah ibu hamil yang mengikuti kegiatan ini sebanyak 19 orang dan media pemaparan menggunakan poster. 


\section{Bagaimana TANDA \& GEJALA ANEMIA pada lbu Hamil?}

1. Mengeluh cepat lelah, letih, lesu, lemas

2. Tampak pucat

3. Pusing

4. Mata berkunang -kunang

5. Kurang semangat

Gambar 1. Media Pemaparan Tentang Anemia pada Ibu Hamil

Adapun karakteristik sosiodemografi Ibu hamil dapat dilihat pada tabel 1.

Tabel 1. Karakteristik Sosiodemografi Kelas Ibu Hamil

\begin{tabular}{lll}
\hline Variabel & $\begin{array}{ll}\text { Jumlah } \\
(n=19)\end{array}$ & $\begin{array}{l}\text { Persentase } \\
(\%)\end{array}$ \\
& & \\
\hline
\end{tabular}

\begin{tabular}{lcc}
\hline Umur & & \\
$<20$ tahun & 1 & 5.3 \\
20-35 tahun & 13 & 68.4 \\
$>35$ tahun & 5 & 26.3 \\
\hline $\begin{array}{l}\text { Pendidikan } \\
\begin{array}{l}\text { Rendah } \\
\text { (SD,SMP,SMA) }\end{array}\end{array}$ & 17 & 89.5 \\
Tinggi (D3/PT) & 2 & 10.5 \\
\hline Pekerjaan & & \\
Kerja & 4 & 21.1 \\
Tidak bekerja & 15 & 78.9 \\
\hline Usia Kehamilan & & \\
Trimester 1 & 0 & 0 \\
Trimester 2 & 11 & 57.9 \\
Trimester 3 & 8 & 42.1 \\
\hline $\begin{array}{l}\text { Gravida } \\
\text { Primigravida }\end{array}$ & 3 & 15.8 \\
Multigravida & 15 & 79.9 \\
Grandemulti \\
Gravida
\end{tabular}

Berdasarkan Tabel 1, dapat diketahui bahwa usia ibu hamil bervariasi yaitu mencakup rentang usia kurang 19 hingga lebih 35 tahun. Sebagian besar ibu hamil berpendidikan SMA, ada ibu hamil berpendidikan SMP. Rata-rata ibu hamil sebagai ibu rumah tangga. Kehamilannya sebagian besar masuk dalam trimester II, dan terdapat 1 grande multi.
Table 2. Distribusi nilai Pre test dan Post Test Pengetahuan Anemia Kelas Ibu Hamil

\begin{tabular}{llllll}
\hline Variabel & Mean & SD & SE & $\begin{array}{l}\text { P } \\
\text { Value }\end{array}$ & $\mathrm{N}$ \\
\hline Pre test & 70.53 & 26.34 & 6.04 & 0.000 & 19 \\
Post tes & 88.94 & 14.48 & 3.32 & & \\
\hline
\end{tabular}

Kelas ibu hamil ini merupakan bagian dari media promosi kesehatan guna meningkatkan pengetahuan ibu hamil seputar kehamilan, persalinan, nifas dan bayi. Pada kegiatan ini difokuskan pada topic anemia pada ibu hamil.

Manusia memperoleh pengetahuan melalui indera penglihatan dan pendengarannya, dengan media poster, majalah, atau sumber informasi dalam bentuk tulisan dan suara seperti seminar, penyuluhan atau pembicaraan orang lain. Peningkatan pengetahuan kesehatan dapat ditingkatkan melalui penyuluhan atau promosi kesehatan (Nasrul Efendi, 2012).

Berdasarkan Tabel 2, ada perbedaan nilai mean antara nilai pre test dan post test. Hasil uji statistik menunjukkan ada hubungan antara pre test dan post test. Kegiatan kelas ibu hamil ini baru pertama kali dilaksanakan di mitra pada era New Normal. Tenaga kesehatan dan ibu hamil tetap memperhatikan protokol kesehatan yang lengkap.

Besar harapan dalam pelaksanaan kegiatan kelas ibu hamil dapat membantu ibu dalam memahami kondisi kehamilan serta dapat memberdayakan diri dengan baik secara mandiri, juga dapat mengetahui apabila ada tanda-tanda bahaya pada kehamilan tertentu ibu hamil harus datang kefasilitas tenaga kesehatan.Telah terbentuk Whatsapp Group (WAG) group ibu hamil agar bisa saling berbagi informasi mengenai kehamilan, persiapan persalinan, perawatan nifas dan perawatan bayi baru lahir, dan persiapan menjadi seorang ibu

\section{SIMPULAN DAN SARAN}

Kelas ibu hamil terbukti dapat meningkatkan pengetahuan ibu hamil. Rekomendasi untuk melakukan tindak lanjut kegiatan kelas ibu hamil secara berkesinambungan dengan meneruskan edukasi kepada sasaran utama yaitu ibu hamil, suami dan elemen keluarga atau pihak terdekat lainnya yang berperan dalam deteksi dini faktor risiko pada kehamilan dengan membentuk kelompok-kelompok diskusi di media sosial, sehingga informasi tetap tersampaikan pada ibu hamil 


\section{UCAPAN TERIMA KASIH}

Terima kasih kami sampaikan kepada Fakultas Kedokteran Kesehatan Universitas Muhammadiyah Jakarta yang telah memberikan hibah dalam pelaksanaan pengabdian kepada masyarakat, suku dinas Jakarta Pusat, Kepala Puskesmas Kecamatan Tanah Abang dan koordinator bidan, yang telah membantu kelancaran dan terlaksananya kegiatan.

\section{DAFTAR RUJUKAN}

Crispin, P. J., Sethna, F., \& Andriolo, K. (2019). Red Cell and Reticulocyte Parameters for the Detection of Iron Deficiency in Pregnancy. Clinical Laboratory, 65(11).

Gari, W., Tsegaye, A., \& Ketema, T. (2020). Magnitude ofAnemia and Its Associated Factors among Pregnant Women Attending Antenatal Care at Najo General Hospital, Northwest Ethiopia. Anemia, 2020.

https://doi.org/10.1155/2020/8851997

Kemenkes R.I. (2020). Pedoman Bagi ibu Hamil, Ibu Nifas dan Bayi Baru Lahir Selama Sosial Distancing.

Kemenkes RI. (2019). Profil Kesehatan Indonesia 2018 [Indonesia Health Profile 2018].

Kementerian Kesehatan Republik Indonesia. (2015). Buku Ajar Kesehatan Ibu dan Anak. In Departemen Kesehatan Republik Indonesia.

Kementrian Kesehatan RI. (2020). Buku KIA Kesehatan Ibu dan Anak (p. 16).

Nasrul Efendi. (2012). Dasar-Dasar Keperawatan (2nd ed.). EGC.

Patriajati, S., \& Sriatmi, A. (2019). Determinants of Mothers' Participation in Antenatal Classes. Jurnal Administrasi Kesehatan Indonesia, $\quad 7(2), \quad 139$. https://doi.org/10.20473/jaki.v7i2.2019.13 9-146

Rofi'ah, S., Widatiningsih, S., \& Chunaeni, S. (2020). Optimalisasi Kelas Ibu Hamil Sebagai Upaya Peningkatan Kesehatan Masa Kehamilan. LINK, 16(1), 42-48.

Saifudin, B. A., Rachimhadhi, T., \& Wiknjosastro, G. H. (2008). IImu Kebidanan (4th ed.). PT Bina Pustaka Sarwono Prawirohardjo.

WHO. (2020). Interim guidance April 2020: Water, sanitation, hygiene and waste management for the COVID-19 virusInterim guidance April 2020. World Health Organisation, April, 1-9. 